\title{
Transatlantica
}

Revue d'études américaines. American Studies Journal

\section{René Alladaye, The Darker Shades of Pale Fire. An Investigation into a Literary Mystery}

Paris, Michel Houdiard Éditeur, 2013

\section{David Rampton}

\section{(2) OpenEdition}

\section{Journals}

Electronic version

URL: https://journals.openedition.org/transatlantica/6314

DOI: $10.4000 /$ transatlantica.6314

ISSN: 1765-2766

Publisher

Association française d'Etudes Américaines (AFEA)

Electronic reference

David Rampton, "René Alladaye, The Darker Shades of Pale Fire. An Investigation into a Literary Mystery", Transatlantica [Online], 1 | 2013, Online since 15 December 2013, connection on 01 February 2023.

URL: http://journals.openedition.org/transatlantica/6314 ; DOI: https://doi.org/10.4000/transatlantica. 6314

This text was automatically generated on 1 February 2023.

\section{(c)}

Creative Commons - Attribution-NonCommercial-NoDerivatives 4.0 International - CC BY-NC-ND 4.0 https://creativecommons.org/licenses/by-nc-nd/4.0/ 


\section{René Alladaye, The Darker Shades of Pale Fire. An Investigation into a Literary Mystery}

Paris, Michel Houdiard Éditeur, 2013

David Rampton

\section{REFERENCES}

René Alladaye, The Darker Shades of Pale Fire. An Investigation into a Literary Mystery, Paris, Michel Houdiard Éditeur, 2013, ISBN 978-2356920935, 19 euros.

1 This is an unusual book about a one-of-a-kind novel. René Alladaye's study is both strikingly original and the product of a sustained engagement with Nabokov's critics. The Darker Shades of Pale Fire provides readers with an attentive account of others' readings and offers a solution to the novel's central mystery. By giving pride of place to Pale Fire's critics, Alladaye's book at times re-enacts the structure of the work it sets out to solve. Yet it seeks to move beyond the intriguing realm of self-reflexive musings by showing how intimately Nabokov's novel engages with the world in which it is read and studied.

2 Alladaye begins by paying handsome tribute to his predecessors Brian Boyd and Priscilla Meyer for their books on Pale Fire, and to those who have published their findings in the countless articles devoted to it. He divides the novel's critics up into puzzle solvers, moralists and metaphysicians, all the while acknowledging the arbitrariness of such categories, and explains his goals as twofold: "opening up" meaning by detailed analysis and "closing down" meaning by seeking to resolve the various questions that the novel poses. This is accurate, disarming, and problematic. The commentary is just what he promises, a large and insightful discussion of matters major and minor. It alone makes the book essential reading for students of the novel. It also neatly provides Alladaye with free rein in what follows, freedom to muse about all 
aspects of the novel's intricate interconnections. The problem comes with attaching coefficients of probability to various conjectures, in both the "opening up" part of his endeavours and the "closing down" one. In the fifty plus years since the novel was published, opening up meaning by painstaking and freewheeling annotation, has proved much easier to engage in than finding answers that strike an extensive readership as definitive. In this second endeavour, Boyd has clearly dominated. Yet as one would expect with such a brilliant novel, his views on the intricacies of Pale Fire have elicited some extraordinarily subtle and sophisticated responses. That this discussion shows no signs of abating seems to me a good thing.

Chapter 1 gives us a publishing history and a sustained comparison between Nabokov's commentary on Eugene Onegin and the novel. Alladaye goes so far as to call the translation and annotation the "origin" of Pale Fire, arguing that the way Kinbote's voice echoes Nabokov's in the Pushkin commentary is important. The points about structure, tone and methodology are compelling (although learning that Nabokov is "far more competent than Kinbote" is less helpful). Chapter 2 is called "A User's Manual." As the title suggests, it is an eclectic undertaking, tackling questions as wideranging as: How are we to read the novel? Is "Pale Fire" a good poem? What poets can be said to have influenced Shade? Is his poem unfinished? What are we to do with the Index? and To what extent does Nabokov anticipate postructuralist criticism? These two chapters constitute intellectual throat-clearing of a helpful kind, as well as suggesting a range of contexts on which Alladaye will draw as he proceeds.

Chapter 3 consists of a detailed account of Mary McCarthy's reaction to Pale Fire, "A Bolt from the Blue," the novel's first great review and one that had a profound influence on subsequent criticism. As Alladaye convincingly shows, McCarthy made readers aware of an impressive number of essential things. Her identification of multiple mysteries provides him with a segue into the authorship question and related issues, which he tackles in earnest from this point on, summarizing, updating, endorsing, arguing with his predecessors, and generally involving himself in a fifty-year conversation with Ackerley, Boyd, Couturier, D. Barton Johnson, Meyer, Ramey, Roth et al.. These exchanges, far too long and complex to summarize here, are again of crucial importance for anyone interested in intensifying the pleasures of the text. The array of hypotheses summarized in the authorship debate is particularly useful.

5 At the centre of Alladaye's argument is his conviction that Holbein's painting The Ambassadors is a key to unlocking the novel's mysteries. Such a bold claim must be supported with evidence rigorously marshalled. It often is, and even the ultimately unconvinced will be struck by Alladaye's ingenuity as he links details in the painting to Nabokov's text. The connections suggested in sentences like "Another theme present in both painting and novel is the representation of the world" are perforce less convincing. Alladaye uses the painting to introduce the idea of anamorphosis, a device whereby the author invites us to see misshapen or distorted objects in their true shape by using an unorthodox perspective. You will have to buy the book to hear how he makes the case for its relevance and for a new authorship candidate.

Where to from here? As Alladaye himself puts it: "The notion of refutation itself is futile: it stands to reason that very different interpretations can, even should, coexist." He does in part believe this, although he enjoys becoming deeply involved in refutation himself. He concludes by admitting that interpreting Pale Fire can result in "fixing" the text for at least a short time, but acknowledges that other readings will follow hard 
upon his, themselves elicited by any account that seemed for a moment to pin things down. I think he is simply right about this: the glorious messiness of Pale Fire often seems to be part of its point, a trait that militates against any attempt to close down meaning. Then there is the fact that the novel, like Lolita, is such a humorous and witty book, something that almost never gets mentioned, let alone dealt with in detail. To judge by Alladaye's intriguing new study, handsomely produced by Michel Houdiard Éditeur, Nabokov's critics will continue to write books that betray our yearning for authority and stability, even as his profoundly disintegrative sensibility keeps reminding us how strange that yearning is.

INDEX

Subjects: Recensions

\section{AUTHORS}

\section{DAVID RAMPTON}

University of Ottawa 